\title{
A Prehistoric Touchstone from France
}

\author{
Christiane Eluère \\ Musée des Antiquités Nationales, Saint-Germain-en-Laye, France
}

\begin{abstract}
Attention bas recently been drawn to ancient touchstones and their traditional use during bistorical times (1-3). A recent find in France gives us the opportunity to raise bere, more particularly, the question of the probable occurrence of touchstones in prehistoric times in Europe.
\end{abstract}

Touchstones are used to provide a rapid, non-destructive assay of gold artefacts. They are still in use today. Differences of 10-20 parts per thousand in gold content may be established, using appropriate reference standards and acids to discolour the contaminant metals (1).

At Choisy-au-Bac(Oise) near Compiègne, north of Paris, alarge settlement located at the confluence of the rivers Oise and Aisne was excavated between 1975 and 1982. It provided numerous remains of the working of bronze and iron during the Late Bronze and the Early Iron Ages. In the corner of a house structure, among pottery sherds was found a black stone as well as a little gold bar ingot which was $1.2 \mathrm{~m}$ from it. A gold ring was also found in the vicinity of the finds (Figure 1). The archaeological layer in which these pieces were discovered is attributed by the excavator, J.-C. Blanchet, to the Late Bronze Age (end of the Eighth Century B.C.).

The black stone (length $6.1 \mathrm{~cm}$ ) has attracted particular attention because of scattered yellow glittering points on its surface. Indeed, a detailed observation of the stone allows us to consider it as a very old touchstone.

An examination of the stone (5) resulted in its identification as a Phtanite black siliceous stone, typically found in pre-Cambrian schists in Brittany or Normandy. This stone was therefore probably brought to Choisy-au-Bac from at least $200 \mathrm{~km}$ away. It is not symmetrical in shape and has three sides smooth and rounded, while the fourth appears to have been formed by an old fracture. On both its flat faces appearvery tiny, but perceptible traces of gold. A macroscopic observation shows that these traces are the remains of larger gold linear markings on the stone. There are no signs of impact on these faces, and the shape of the rock and its nature have led to the conclusion that it was used as a touchstone.

Gold grains (on the average $\mathbf{4 0}$ to 100 microns in length) are distributed in many places on the stone but three essentially linear gold markings can be distinguished (Figure 2). S.E.M. analyses (6), carried out on a flat face supporting these markings, have confirmed that they are fairly pure gold, containing only small amounts (1-5\%) of silver. Copper, if associated with the gold, was present in concentrations below detection limits. It was therefore probably absent from the alloys from which the marks were formed. It is perhaps worth noting that gold alloys as pure as those from which the marks were generated are not common in artefacts of the Late Bronze Age but appear frequently in jewels of the early Iron Age, particularly in those from the eastern part of France or South Germany $(7,8)$.
This stone was therefore probably in use in this latter period at the end of the Eighth Century, or the beginning of the Seventh Century B.C., which corresponds with the dating of the archaeological layer. Indeed, in this period we generally find artefacts from the Bronze Age cultures still associated with materials or technologies of the new Iron Age cultures.

Analysis of the ingot and the ring by X-ray fluorescence spectrometry has shown that they contain much more silver than the markings on the touchstone. The silver content in the ingot was found to be 15 per cent and that of the ring 25 per cent. The copper contents were low in each case, being less than 1 per cent. In their richness in silver, these gold alloys are similar to contemporaneous gold finds from other parts of France (9).

The close association of the three objects indicates that a goldsmith's workshop was probably operated on this site and that the finds constituted part of his stock. The sites of such workshops, through different periods and cultures, have invariably yielded tools, raw materials, sometimes a scale, often a touchstone. For example, Ashanti goldsmiths carried such equipment wrapped in a textile inside a leather case (10).

Stone tools abundantly used by prehistoric metalworkers or goldsmiths are far from being fully known, though some studies have been undertaken, for example, on the quartzite tools of the early metallurgists in North-Western Europe (11). Thus, the touchstone from Choisy-au-Bac may be compared with the one from the Iron Age hillfort at Hengitsbury Head (Hampshire) $(12,13)$ which carried gold traces and was found also on a metallurgical site, but which seems to have been lost.

The study of the touchstone from Choisy-au-Bac, securely dated, has stimulated a search for other similar tools in France. As a result, information can be presented concerning four stone tools, on which traces of gold have been found:

A stone of brown-green colour, from La Baume Latrone (Gard, South of France), (M.A.N. 78.737D), shaped like a short axe (5.8 $\mathrm{cm}$ ) has numerous obvious gold markings on both its main faces (Figure 3). The stone is an eclogite, a metamorphic rock, and could have been transported from the south of the Massif Central where it occurs. At least three different alloys were found by scanning electron microscopy to be responsible for the gold markings on it, namely: (1) a very pure gold, almost without silver; (2) an alloy of about 80 per cent gold, 2 percent silver and 15 percent copper; (3) 
an alloy of about 95 per cent gold, 1 per cent silver and 4 per cent copper. This stone was collected at the end of the Nineteenth Century in a cave which yielded, inter alia, a lot of Neolithic, early Bronze Age, and especially Copper Age finds (14).

Unfortunately there is no detailed information as to the direct context and dating of this 'touchstone' but, if the object and its gold traces could be associated with the main use of the cave (early Second Millennium B.C.), this tool might be established as dating from the earliest days of goldworking in Southern France (15). At present we cannot-besure that its use as a touchstone was not a 're-use' at a later date.

A thick black stone (M.A.N. 446) $14.8 \mathrm{~cm}$ long, in the shape of a prehistoric polished axe (without cutting edge anymore) is probably of French origin. It was acquired in 1862 by the Musée des Antiquités Nationales as part of a very large collection (Charvet collection) containing prehistoric as well as Roman or Merovingian finds. The nature of the stone is again Phtanite, very similar to the schists from Brittany, and it carries gold traces present in some short scratches. These traces have been found by S.E.M. to contain gold (80-85 per cent), silver (11-13 per cent) and copper (3-6 per cent).

The very archaic shape of the object is indisputable. The dating of the gold traces is, of course, more questionable. However, this type of alloy has been encountered in finds from the Late Bronze Age.

Another tool (M.A.N. 382), obviously a touchstone, $3.4 \mathrm{~cm}$ long, with gold traces was given to the Musée des Antiquités Nationales by Napoleon III, in 1862. Unfortunately, there is no precise locality for it, but it probably comes from 'the Seine River in Paris'. A break at one side of the object seems to have resulted from use of a mechanical saw, and its top presents some little flat facets (mechanical abrasion?) unusual on prehistoric polished stones.

Although this tool may be old, its use as a touchstone may be more recent than prehistoric. It is again a Phtanite from Brittany. Two kinds of alloys at least were detected by S.E.M. analysis of the gold traces: (1) a gold (92-94 per cent), silver (2.3 per cent), copper 2-4 per cent) alloy; (2) a gold (ca. 83 per cent), silver ( 5 per cent), copper (12 per cent) alloy.

A very odd cylindrical stone $(24.5 \mathrm{~cm}$ long $)$ was found fortuitously ten years ago in Plouasne (Cötes-du-Nord, Brittany), during the ploughing of a field. The region is rich in prehistoric occurrences, but no precise context accompanies this object which is made of basalt, probably of local origin. It is covered on its medial part by very thin but long gold traces. The analysis of one gold particle by $\mathrm{X}$-ray fluorescence spectrometry indicated that it consisted of pure gold with only small amounts of silver. This object is in a private collection in Paris and was kindly loaned for study.

The question of the probable use of touchstones in Europe in prehistoric times has also arisen in connection with wedge shaped artefacts of prehistoric types and manufacture carrying gold traces, found in southern Scandinavia (16). Similar to many stone objects found in male graves of the beginning of the Bronze Age (early Second Millennium), two black slate tools with gold traces have been examined. Three different alloys were detected as responsible for the traces. They contained respectively on average 85.9 per cent, 98 per cent and 79.3 percent gold. The copper content was less than 1 percent in each case. Here again this purity could eventually match that of gold objects of the Early Bronze Age from Scandinavia (17).

The use of touchstones to test the purity of gold seems to indicate the goldsmiths of the periods concerned were well aware of the fact: that gold could be obtained, or present itself, in different degrees of purity, and that they were not unaquainted with gold refining processes. In Mesopotamia, refining was apparently not practiced before the end of the Third Millennium B.C., and early texts from $\mathrm{Ur}$, for example, mention numerous kinds of gold colours and qualities $(18,19)$.

Two Mesopotamian finds $(20,21)$ of so called 'touchstones' are often mentioned but conclusions as to their nature must be revised.

The one was found in a goldsmith's tomb at Tello(Third Dynasty of Ur, end of the Third Millennium B.C.) in association with a copper scratcher, a copper bowl and rings, seven stone weights kept in a textile bag, a copper scale, food jars and pots. We have had an opportunity to examine the stone tools, kept in the Louvre (Département des Antiquités Orientales) (22). A fragment of hematite of irregular shape as well as a black pebble (Peridotite Serpentinite found in areas from Turkey to the Himalayan regions) may not be considered as touchstones. They carry no traces of gold and they are not suitable for use as touchstones. They may have been used as burnishing stonies.

The other reputed touchstone is said to have been found in a very large goldsmith hoard discovered in the temple at Larsa, Mesopotamia (Eighteenth Century B.C.), among raw material of gold, silver, stone weights, tools in bronze and stone, seals and gemstones. It is a black stone of flat and rectangular shape - a possible touchstone shape - which has been identified as hematite. There is no reference to the presence of traces of gold in it, so its identification as a touchstone must be regarded as of doubtful validity. It may also have been used rather as a burnishing stone.

In Western Europe, the need to measure the gold content of gold alloys could have arisen at the end of the Bronze Age (end of the First Millennium B.C.) when copper alloys were important (23), or during the Iron Age when it seems that very pure gold was sometimes requested and used, and may have been produced by refining (24). In earlier periods, during which goldsmiths were apparently using only native gold, the role of assaying is not so obvious. It could have served eventually only to distinguish gold from bronze, as already suggested by Rausing et al. (25), or to differentiate native golds of various origins containing different percentages of silver.

The Choisy-au-Bac touchstone demonstrates that assaying for gold was known in France in the Eighth-Seventh Centuries B.C. The Phtanite is a typical material for the making of touchstones and is still used for this purpose today. We do not know the exact process of assaying in prehistoric times, as the touchstones are used with 


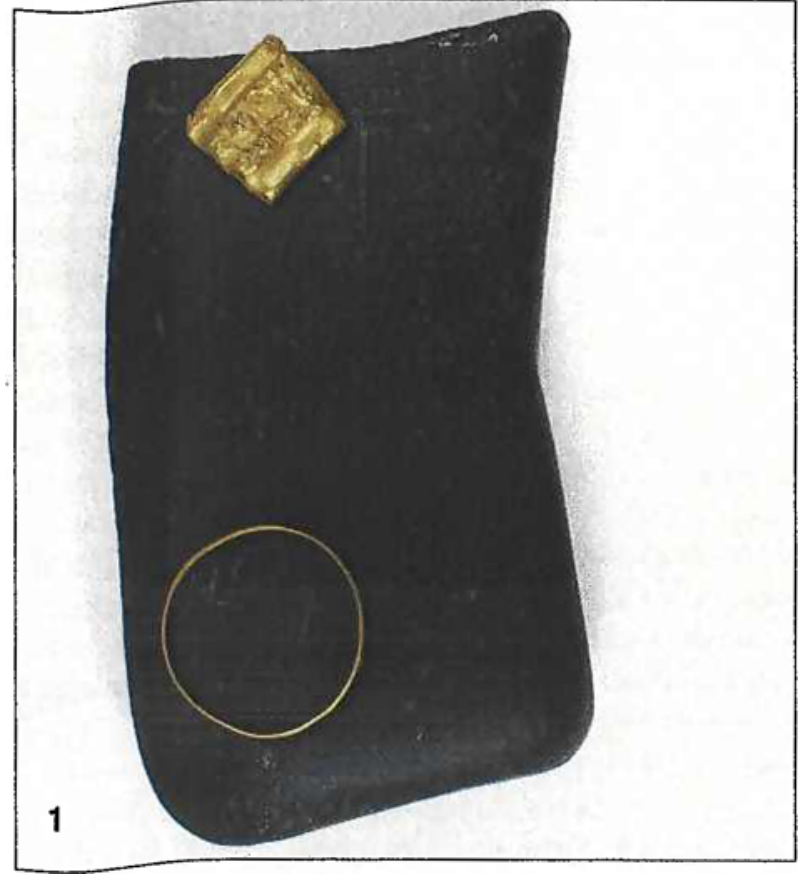

Fig. 1 Touchstone from Choisy-au-Bac (Oise): 6,1 cm long, 1,6 cm maximal thickness. On the right: little bar ingot; on the left: gold ring from the same site (photo C.E.)

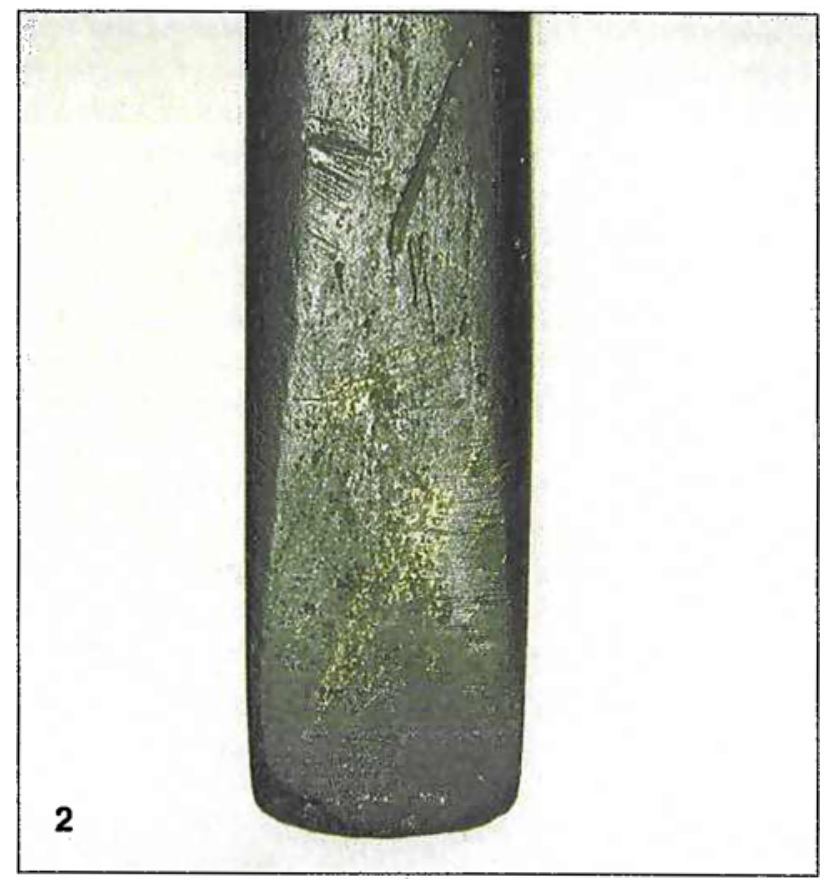

Fig. 2 Gold traces on a Scandinavian wedge-shaped artefact (photo kindly lent by Dr. Rausing)

Fig. 3 Authenticated and disputed touchstones. Top row from left to right: The stones from Choisy-au-Bac (Oise); Baume Latrone (Gard); Tello (Mesopotamia); and ine 3 Aut (M.A.N. 382) stone. In the centre: The stone tool from Plouasne (Cötes-du-Nord, France) Bottom right: The stone 'France' (M.A.N. 446) (photo C.E.)

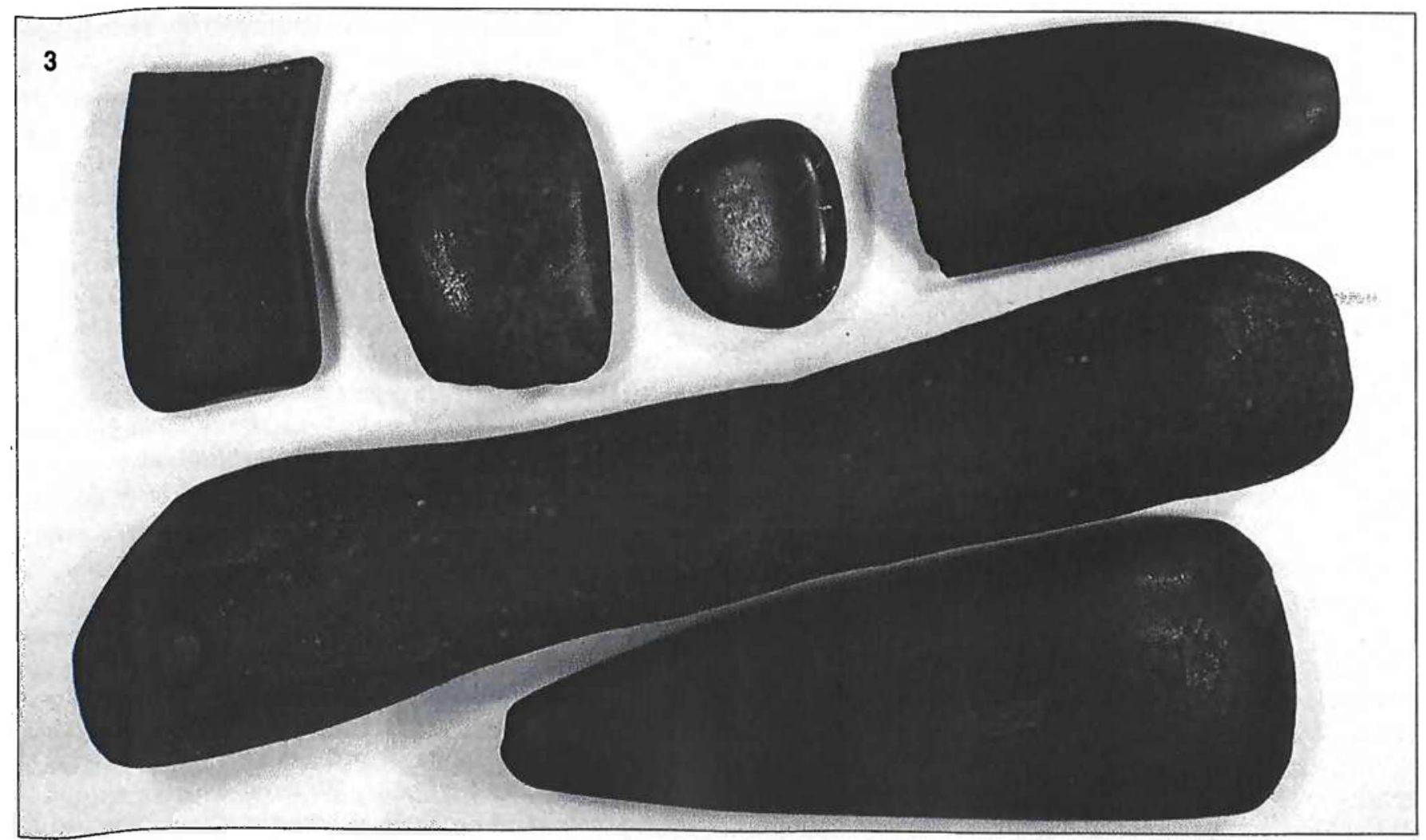




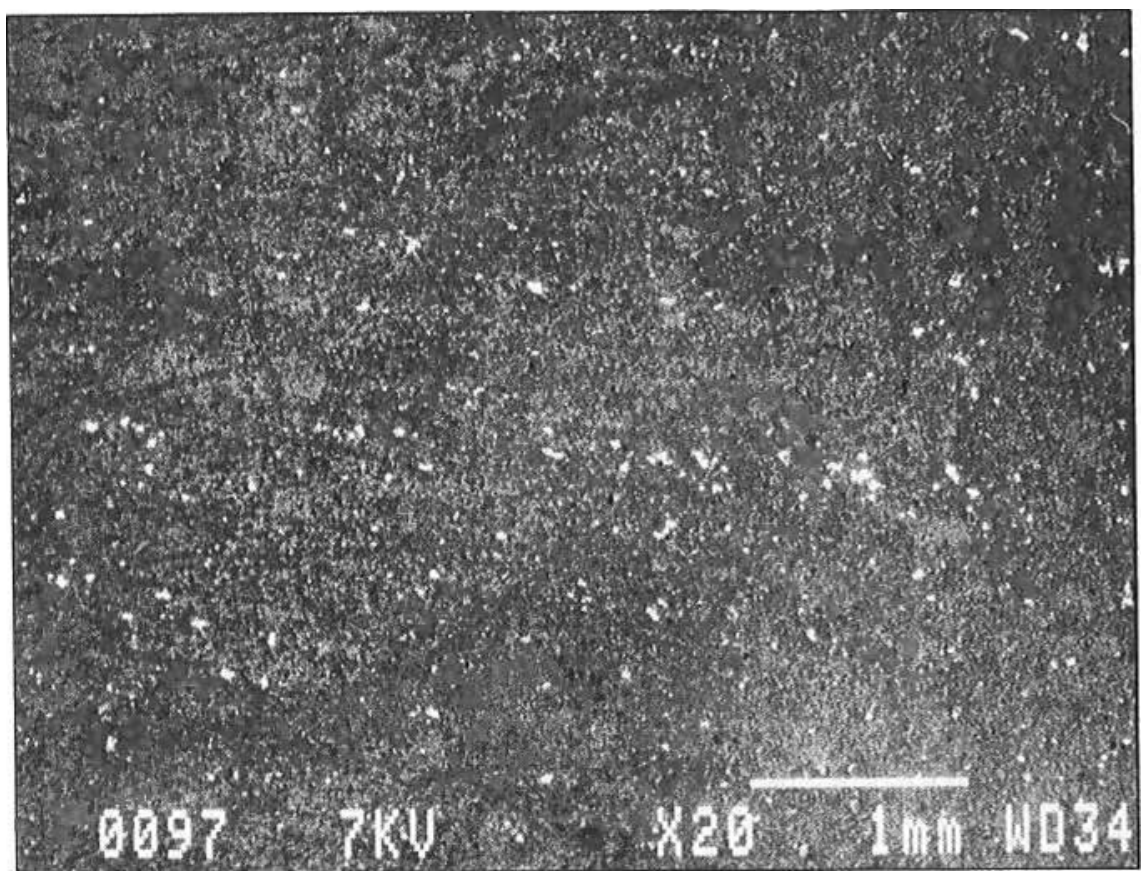

Fig. 4 Macroscopic view of the gold traces (white points) on the touchstone from Choisy-au-Bac (photo S.E.M. L.R.M.F.) mineral acids in modern times. It is generally admitted, therefore, that the ancient goldsmiths must have had to rely on the colour of the touchstone markings for assessing the characteristics of these alloys. However, it is perhaps possible that they knew how to modify the colours of the markings with organic acids of vegetable origin. We know that such acids were prepared by some pre-Columbian tribes to effect surface entichment of gold-copper alloys (26)

In conclusion, genuine touchstones dating to before the First Millennium B.C. have so far been found only very rarely. Their identification calls for detailed examination in each instance. Account must also be taken of the possible later use of artefacts as touchstones, especially where they are not found in a well authenticated context in archaeological layers (27), unlike the stone of Choisy-au-Bac, which is one of the oldest known touchstones from Europe.

\section{References and Notes}

1 E. Wälchli, Touching Precious Metals, Gold Bull., 1981, 14, (4), 154-158

2 A. Oddy, Assaying in Antiquity, Gold Bull., 1983, 15, (2), 52-59

3 A. Oddy, Touchstones: Some Aspects of Their Nomenclature, Petrography and Provenance, Journal of Archaeol. Science, 1985, 12, 59-80

4 J.C. Blanchet, Les Premiers Métallurgistes en Picardie et dans le Nord de la France, Mém. Soc. Préhist. Franc., 1984, 17, 414

5 The examination was carried out in the Laboratoire de Minéralogie du Muséum d'Histoire Naturelle à Paris, by Dr. Latouche. The S.E.M. and X-ray fluoroescence spectrometric analyses were carried out in the Iaboratoire de Recherche des Musées de France, by Dr. A.R. Duval. I am most grateful for their help

6 The results of the analyses of these stone tools are to be considered indicative only because of the microscopic dimensions of samples, and our lack of knowledge of the treatments to which they were subrnitted

7 C. Eluère, Les ors préhistoriques, L'Age'du Bronze en France, Paris, 1982, pp. 201-205

8 C. Eluère, Goldwork of the Iron Age in 'Barbarian' Europe, Gold Bull., 1985, $18,(4), 144-155$

9 C. Eluère, 1982 Reference 7, Figure 182: We published in this Figure, two spectrographic analyses carried out in Stuttgart by $A$. Hartmann. These reflect higher copper contents, namely 2.3 per cent for the ingot and 7.5 percent for the ring. These higher copper contents are possibly more in line with those of Atlantic gold finds. However, the significance of such differences in analytical figures is at present under study

10 M.D. Macleod, The Asante, London, 1981, p. 133

11 J. Butler and van der Waals, Bell Beakers and Early Metal Working, Palaeobistoria, $1967,63-75$
12 W. Gowland, 'Report on the Metals and Metallurgical Remains' in Appendix II, 'Evacuations at Hengitsbury Head in 1911-12' by J.P. Bushe Fox, Reports of the Royal Research Committee of the Society of Antiquaries of London, 1915, No. 3, $72-83$

13 A. Oddy, 1985, Reference 3, 71
14 M. Louis and E. Drouot, Les Baumes Latrone, Cabiers Ligures, BordigheraMontpellier, 1953, 2, 173

15 C. Eluère, 1982, Reference 7, 117-129

16 M. Ahlberg R. A ksellsson B. Forkmannand G Rausing in 'Gold Traces on Wedge Shaped Artefacts from the Late Neolithic of Southern Scandinavia Analysed by Proton Induced X-ray Emission Spectroscopy, Archaeometry, 1976, 18,(1), 39-49

17 A. Hartmann, Goldfunde aus Europa, Studien zu den Anfängen der Metallurgie, 1982,5 , Table 22

$18 \mathrm{H}$. Limet, Le Travail du Métal au Pays de Sumer au Temps de la llle Dynastie d'Ur, Paris, 1960, 41-163

19 P.R.S. Moorey, Materials and Manufacture in Ancient Mesopotamia, British Arcbaeological Reports, 1985, 237

20 D. Arnaud, Y. Calvet and J.-L. Huot, Ilsu-Ibrisu, Orfevre de l'Ebabbar de Larsa. Syria, 1979, LVI, Figure 8

21 H. de Genouillac, Fovilles de Telloh, II, Paris, 1936, pp. 31 and 122

22 I thank Professor Amiet, Chief Curator of the Department; and F. Tallon, Chargée de Mission, for their permission to study these stones

23 C. Eluère, 1982, Reference 7

24 C. Eluère, 1985, Reference 8

25 See note 12

26 T. Del Solar and M. Grimwade, Ia Mise en Couleur Aurum, 1982, 12, 40

27 C. Eluère, Attentionaux pierres de touche, Bull Soc Prébist. Franc., 1985, No. 